e-ISSN: 2550-1313 | p-ISSN: 2087-9849

http://jurnal.fkip.unila.ac.id/index.php/jpp/

\title{
Supervision in Coaching of Early Childhood Teachers in Sub-District Banda Raya, Indonesia
}

\author{
Fitriani, Murniati, Niswanto \\ Postgraduate School of Educational Administration, Syiah Kuala University, Indonesia \\ *Corresponding email:fitriani@gmail.com
}

Received: 27 October $2019 \quad$ Accepted: 21 July $2020 \quad$ Published: 25 November 2020 Abstract: Supervision in Coaching of Early Childhood Teachers in Sub-District Banda Raya, Indonesia. Objectives: The purpose of this study was to determine the planning, implementation, and follow-up of the supervision carried out by the supervisors in developing early childhood education teachers in Banda Raya Sub-District, Indonesia. Methods: A descriptive method with a qualitative approach was used in this study. The data needed were collected through observation, interviews, and documentation. The subject of this study consisted of supervisors, principals, heads of teacher working groups, and senior teachers of early childhood education. Findings: The results of this study indicates that (1) the supervision was planned by the supervisors in order to improve the ability of early childhood education teachers in doing their main tasks. In addition, (2) the supervision was conducted through a coordination so that there was no overlapping of the supervision schedules of the school principal and teachers. Finally, (3) this supervision was then followed up with guidance on teachers who encountered obstacles through discussions, case conferences, and question and answer sessions.

Keywords: Supervision, early childhood teachers, Indonesia.

Abstrak: Pengawasan dalam Pembinaan Guru Anak Usia Dini di Kecamatan Banda Raya, Indonesia. Tujuan: Tujuan dari penelitian ini adalah untuk menentukan perencanaan, implementasi, dan tindak lanjut dari pengawasan yang dilakukan oleh pengawas dalam mengembangkan guru pendidikan anak usia dini di Kecamatan Banda Raya, Indonesia. Metode: Metode deskriptif dengan pendekatan kualitatif digunakan dalam penelitian ini. Data yang dibutuhkan dikumpulkan melalui observasi, wawancara, dan dokumentasi. Subjek penelitian ini terdiri dari pengawas, kepala sekolah, kepala kelompok kerja guru, dan guru senior pendidikan anak usia dini. Temuan: Hasil penelitian ini menunjukkan bahwa(1) pengawasan direncanakan oleh pengawas dalam rangka meningkatkan kemampuan guru pendidikan anak usia dini dalam melakukan tugas utama mereka. Selain itu, (2) pengawasan dilakukan melalui koordinasi sehingga tidak ada tumpang tindih jadwal pengawasan kepala sekolah dan guru.

Kata kunci: Supervisi, guru PAUD, Indonesia.

\section{To cite this article:}

Fitriani., Murniati., \& Niswanto., (2020). Supervision in Coaching of Early Childhood Teachers in SubDistrict Banda Raya, Indonesia. Jurnal Pendidikan Progresif, 10(3), 485-491. doi: 10.23960/ jpp.v10.i3.202010. 


\section{INTRODUCTION}

Early Childhood Education is a very basic and strategic education in the development of human resources (Betranet.al., 2019; Piper, Merseth, \&Ngaruiya, 2018; Yoshikawa et.al., 2018). In accordance with article 28 of Act Number 20 of 2003 concerning the National Education System, early childhood education is preschool education. Preschool education is the implementation of school education or basic education. In Government Regulation Number 27 of 1990, Chapter II Article 3 states that "Preschool education aims to help lay the foundation towards the development of attitudes, knowledge, skills and creativity needed by students in adjusting to their environment and for further growth and development."

The form of this preschool education unit consists of kindergartens found in the school education pathway, and the Play and Child Care Group is on the Education Out-of-school track (Denessen, 2019; Verhoeven, Poorthuis, \&Volman, 2019; Wang, 2019; Rintakorpi, 2016). Students in Playgroup and Child Custody are at least 3 (three) years old. Based on the provisions, it is illustrated that the implementation of Early Childhood Education is at the preschool level(Macdonaldet.al., 2017; Black et,al., 2016; Akinrotimi, \&Olowe, 2016).Further mentioned in law No. 20 of 2003 (Chapter-I, Article 1, point 14) that early childhood education is an effort to provide guidance to children from birth to the age of six years through the provision of educational stimuli for growth and physical development of children to have readiness to enter further education.

Early Childhood Education is very important. The existence in today's household life is increasingly necessary, because many mothers work outside the home, while domestic helpers are increasingly scarce and expensive, especially in big cities (Parks, 2018; Shuey\&Leventhal, 2018; Broman \& Samuelsson, 2017). The importance of education for early childhood is based on the results of various studies that state that early age is a critical period in child development (Black et.al., 2017; Bundy et.al., 2017). Based on neurological studies, at birth the baby's brain contains about 100 billion neurons that are ready to make connections between cells. During the first years, the baby's brain developed very rapidly by producing trillions of connections between neurons that exceeded the number of needs. This connection must be strengthened through a variety of psychosocial stimuli, because non-reinforced connections will experience shrinkage and destruction. This is what will affect the level of intelligence of children.(Nair, 2020; Carter, 2019; Hertz, 2018).

The process of education and teaching that takes place in an educational institution requires systematic and planned coordinating efforts (Stevanopaet.al., 2018). One of the efforts in this direction can be realized through the implementation of supervision. Supervision is nothing but the application of democratic principles in achieving educational goals, so that human potential can develop continuously, both in a personal and shared context, so that everyone can participate in a community, especially an educational institution. In terms of educationsupervision is defined by procedures giving direction and conducting critical assessments of the teaching process (Winslow, Eliason, \&Thiede, 2016). The target of the supervision by the relevant supervisory office is to improve teacher development and the quality of education. The process of improving the quality of education is by making efforts to improve the ability of teachers through supervision by supervisors. Supervisors as educational staff who aim to streamline the functioning of education personnel. Supervisors have a more difficult task, namely ensuring that the functions of personnel and organizations in school run as they should. This function will guarantee the process of 
education and learning in each school. Reliable supervisors are those who have the ability to guarantee the implementation of key functions of personnel and organizations.

Problems that are still encountered now are that supervisors often do not know their duties and functions properly, so that when carrying out the supervision tasks they are not optimal. Another problem is that there are still supervisors who do not have an educational background that is in line with the teachers who are trained, especially supervisors who provide guidance to Early Childhood Educationinstitutions. In addition, the obstacles faced by supervisors in the implementation of supervision include: there are still many teachers who do not understand their functions and roles well, there are still Early Childhood Education teachers leaving their duties. Quality is a comprehensive overview of education services both internally and externally in an effort to satisfy the expected needs. Early Childhood Education has educational learning programs (games), professional staff, and adequate facilities, all of which require good management. PAUD is designed so that children can learn in a state of pleasant mood by providing opportunities for children to find knowledge and actually use it.Realizing the vision and mission, that is by writing it through programs, activities, and creating the next step by organizing the implementation program and a mature and flexible plan to be implemented within a certain period of time gradually.

Basically, the quality of education can be seen as a state, condition, appearance, or performance demonstrated by each component of the education unit in achieving a predetermined goal.In educational institutions, the improvement of education quality becomes effective when each policy maker plays an active role in directing every improvement. Today's efforts to improve the quality of education are continuously carried out by all stakeholders in the efforts to develop human resources and the development of the nation's character. Improving the quality of education is part of the Government's efforts to improve human resources and improve the quality of life of Indonesian society and in hopes of answering the challenges of world education competition.

\section{METHODS}

This study seeks to gather data and information related to supervisory supervision in guiding teachers in Early Childhood Education in BandaAceh Sub-District, Banda Aceh City, using descriptive methods and qualitative approaches. Data collection is carried out through observations, interviews, and documentary studies. Then proceed with analysis and conclusions about supervisory supervision in guiding teachers in Early Childhood Education. Research subjects were supervisors, principals, and senior teachers.

\section{- RESULT AND DISCUSSION \\ A. Supervisor planning}

The results of the study showed that the planning of academic supervision by the supervisor of Early Childhood Education in Banda Raya Sub-District, Banda Aceh City was prepared at the beginning of the new school year. Supervision planning is made by implementing goals. The goal is to improve the ability of teachers to manage Early Childhood Educationeducation, starting from planning, implementing, and evaluating. The hope of the supervision is to increase children's knowledge obtained from the increase in the teacher's ability to manage learning. The scope of the supervision planning carried out by the supervisor at the Early Childhood Education Banda Aceh District of Banda Aceh was the development of a good education syllabus. Objectives in planning supervision by supervisors to see the teacher's ability to manage 
learning, starting fromplanning, implementing, and evaluating.

Every teacher has different abilities and weaknesses, also requires the ability of the teachers. Supervision as an effort to help teachers improve their professional abilities, according to their needs in learning. Every assistance and guidance must be planned according to the needs of the teacher [3]. This supervision planning is the same as planning in the education management function so it needs to be mastered by supervisors, both supervisors and principals. Likewise in supervision planning that has a very important position in the series of learning processes. Planning supervision programs is the preparation of planning documents, monitoring, attacking activities to help teachers develop their abilities, manage the learning process to achieve learning goals. Based on expert opinion above, it can be seen that the purpose of a plan is as a supervisory standard regarding when the implementation and completion of an activity, knowing who is involved, getting systematic activities, minimizing unproductive activities, giving overall information about work activities, detect what will be found and direct the achievement of goals.

B. Implementation of supervisory supervision in teacher development

The supervision program that had been made by the Early Childhood Education head in Banda Raya District, Banda Aceh City first communicated to the teachers. The supervision program that has been created and will be implemented is notified to the teachers first, both through teacher meetings and in daily meetings. The head of Early Childhood Education in Banda Raya Subdistrict, Banda Aceh City applied several principles of academic supervision, including: creating harmonious, sustainable, democratic and constructive relationships. Supervision activities that pay attention to assistance that can improve the professional abilities of teachers of professional abilities are reflected in the ability of teachers to provide assistance to their students, resulting in changes in academic behavior in their students. Academic supervision is also carried out by supervisors in a constructive and creative manner, by encouraging the initiative of teachers to actively create a conducive atmosphere that can arouse the creative atmosphere of students in Early Childhood Education.

The approach of supervision carried out by Early Childhood Education Supervisors in Banda Raya City, Banda Aceh City is a direct and indirect approach, and is determined based on the problems faced by the teacher. The approach used in implementing supervision is often based on psychological principles. An approach to supervising education is very dependent on the characteristics of the supervised teacher. Broadly speaking there are three approaches in educational supervision, namely: (1) direct approach (directive approach), (2) indirect approach (non directive approach), (3) approach collaborative approach [5]. The direct approach is an approach to supervision where in an effort to improve teacher capacity, the supervisor's role is greater than the role of the supervised teacher. An indirect approach is a supervision approach where in an effort to improve teacher capacity, the supervisor's role is smaller than the role of the supervised teacher. A collaborative approach is an approach in which efforts to increase the ability of teachers, the role of supervisors are as large as the role of supervised teachers.

C. Follow-up supervision of supervisors in teacher development

Follow-up from the results of the implementation of supervision carried out by the supervisor in guiding teachers in Early Childhood Education in Banda Raya Sub-District, Banda Aceh City. The data obtained from observation and dialogue with supervisors and teachers. To 
follow up on research findings, supervisors or supervisors analyze and evaluate all findings from observations on the implementation of teacher learning activities both concerning the completeness of learning tools and the course of implementing student learning activities in the classroom. Follow-up findings of supervision are prioritized for those who have obstacles in carrying out their duties, both in terms of limited knowledge and management of learning in the classroom. Academic supervision or teaching supervision is to help teachers improve their ability to manage the learning process, especially for those who have difficulty implementing learning. In line with this situation, the results of the followup of academic supervision by supervisors are ended with concrete steps contextually as a way out of the problems faced by the teacher in the learning process and future improvement efforts to improve and improve the quality of learning. The results of supervision need to be followed up to have a real impact on teacher professionalism. This real impact is expected to be felt by the community and stakeholders.

Thus, evaluating the implementation of the supervision provides benefits for supervisors and teachers. Supervisors can find out the extent to which targets have been achieved in carrying out their capacity building. The teacher is also expected to be able to accept the evaluation results openly, and receive advice and direction from the supervisor or supervisor for repairs. In line with the explanation above, evaluation is a process that determines conditions, where a goal has been achieved. From the evaluation results, information will be available on the extent to which a particular activity has been achieved so that it can be found the difference between the standard that has been set with the results that have been achieved. Follow-up steps are carried out through a dialogical process between supervisors and supervised ones to discuss steps to improve the shortcomings and weaknesses experienced by the teacher in the learning process. The approach taken by supervisors must be partnership and family.

\section{CONCLUSION}

Supervision planning carried out by the supervisor is to arrange supervision plans in the Early Childhood Education that is under his supervision. This process is carried out at the end of each new school year. Planning is made so that Early Childhood Education teacher development is achieved properly. The supervisor prepares a supervision schedule that contains the date, when a teacher is supervised, in the form of a matrix. Implementation of supervision is carried out by supervisors, which leads to efforts to guide teachers. In the implementation, there is coordination between supervisors and principals, so that supervision activities run well. Supervision activities carried out include classroom guidance, class observation, impromptu tests, case conferences, documentation, interviews, questionnaires, and written reports. In following up on the results of supervision, supervisors have conducted educative and persuasive approaches such as coaching teachers who have difficulty through discussions, case conferences, question and answer between supervisors and teachers about the obstacles faced in developing teachers.

\section{REFERENCES}

Akinrotimi, A. A., \&Olowe, P. K. (2016). Challenges in implementation of early childhood education in nigeria: The way forward. Journal of education and practice, 7(7), 33-38.

Bertrand, J., Butler, E., Fesseha, E., Maich, K., McCuaig, K., McLean, C., ...\& Gabrielle, Y. (2019, January). Quality Early Childhood Education the Need for Special Education Services: A Symposium. In 2019 Conference of the Canadian Society for the Study of Education. 
Black, M. M., Walker, S. P., Fernald, L. C., Andersen, C. T., DiGirolamo, A. M., Lu, C., ... \&Devercelli, A. E. (2017). Early childhood development coming of age: science through the life course. The Lancet, 389(10064), 77-90.

Broman, I. T., \& Samuelsson, I. P. (2017). Early childhood education, gender relations and equality among parents and families in Sweden. In Nordic dialogues on Children and Families (pp. 63-78). Routledge.

Bundy, D. A. P., Silva, N., Horton, S., Jamison, D. T., \& Patton, G. C. (2017). Evidence of Impact of Interventions on Growth and Development during Early and Middle Childhood—Child and Adolescent Health and Development.

Carter, R. (2019). The human brain book: An illustrated guide to its structure, function, and disorders. Penguin.

Denessen, E. (2019). Parental involvement in the Netherlands. Parental Involvement Across European Education Systems: Critical Perspectives, 64.

Handelzalts, A. (2019). Collaborative curriculum development in teacher design teams. In Collaborative Curriculum Design for Sustainable Innovation and Teacher Learning (pp. 159-173). Springer, Cham. Hertz, J. A. (2018). Introduction to the theory of neural computation. CRC Press.

Macdonald, K., Brinkman, S., Jarvie, W., Machuca-Sierra, M., McDonall, K., Messaoud-Galusi, S., ...\& Vu, B. T. (2017). Pedagogy versus school readiness: The impact of a randomized reading instruction intervention and community-based playgroup intervention on early grade reading outcomes in Tonga. The World Bank.

Nair, K. P. (2020). The Brain-Behavior Link: A Conundrum. In Food and Human
Responses (pp. 25-44). Springer, Cham. Parks, A. N. (2018). How do African American Mothers in a Rural Community Perceive Resources for Supporting Family Involvement in the Early Years?.Early Childhood Education Journal, 46(5), 557-565.

Piper, B., Merseth, K. A., \&Ngaruiya, S. (2018). Scaling up early childhood development and education in a devolved setting: Policy making, resource allocations, and impacts of the Tayari school readiness program in Kenya. Global Education Review, 5(2), 47-68.

Rintakorpi, K. (2016). Documenting with early childhood education teachers: pedagogical documentation as a tool for developing early childhood pedagogy and practises. Early Years, 36(4), 399-412.

Shuey, E. A., \&Leventhal, T. (2018). Enriched early childhood experiences: Latina mothers' perceptions and use of centerBased child care. Early Childhood Research Quarterly.

Stepanova, N. A., Sannikova, L. N., Levshina, N. I., Yurevich, S. N., \&Ilyina, G. V. (2018). Methodological performance evaluation by teachers in preschool educational intitutions. International Journal of Cognitive Research in Science, Engineering and Education, 6(2), 67.

Verhoeven, M., Poorthuis, A. M., \&Volman, M. (2019). The role of school in adolescents' identity development. A literature review. Educational Psychology Review, 31(1), 35-63.

Wang, M. (2019, August). Research on the Space Design of Kindergarten Activity Unit Example of Graduation Design of South China University of Technology. In 5 th International Conference on Arts, Design and Contemporary Education 
(ICADCE 2019). Atlantis Press.

Winslow, R. D., Eliason, M., \&Thiede, K. W. (2016). Comparing the effect of two internship structures on supervision experience and learning. Journal of Organizational \& Educational Leadership, 1(2), 4.

Yoshikawa, H., Wuermli, A. J., Raikes, A., Kim, S., \&Kabay, S. B. (2018). Toward high quality early childhood development programs and policies at national scale: Directions for research in global contexts. Social Policy Report, 31(1), 1-36. 